Nigerian Journal of Physiological Sciences 24 (1-2): 53 - 57 @ Physiological Society of Nigeria, 2009

Available online/abstracted at http://www.biolineinternational.org.br/nps; www.ajol.info/journals.njps; www.cas.org

\title{
EFFECT OF DIETARY GARCINIA KOLA SEED ON SELECTED SERUM ELECTROLYTES AND TRACE METALS IN MALE ALBINO RATS
}

\section{P. O. AGADA AND V. B. BRAIDE*}

Department of Pharmacology, Faculty of Basic Medical Science, College of Medical Sciences, University of Calabar, P.M. B. 1115, Calabar, Nigeria. E-mail: victorbraide@yahoo.com. Tel: $+2348034048101$

Summary: The effects of various doses of dietary intake of Garcinia kola seed powder [incorporated in animal feed at levels of $5 \% \mathrm{w} / \mathrm{w}, 10 \% \mathrm{w} / \mathrm{w}$ and $20 \% \mathrm{w} / \mathrm{w}$ and fed daily for six weeks] on serum levels of selected electrolytes $\left(\mathrm{K}^{+}, \mathrm{Na}^{+}, \mathrm{CI}^{-}, \mathrm{HCO}_{3}^{-}, \mathrm{Mg}^{2+}\right.$ and $\left.\mathrm{Ca}^{2+}\right)$ and trace metals $\left(\mathrm{Cu}^{2+} \mathrm{Zn}^{2+}\right.$ and $\left.\mathrm{Mn}^{2+}\right)$ were studied in male albino rats $(100-150 \mathrm{~g}$ body $\mathrm{wt})$. The pair - fed controls received basal feed diet daily for six weeks. Results showed a significant $(\mathrm{P}<0.05)$ dose dependent elevation of serum $\mathrm{CI}^{-}, \mathrm{HCO}_{3}^{-}, \mathrm{Ca}^{2+}$, $\mathrm{Mg}^{2+}, \mathrm{Cu}^{2+}, \mathrm{Zn}^{2+}$ and $\mathrm{Mn}^{2+}$. These findings point to a possible relationship with already documented histopathology of various organs (such as the gonads) induced by Garcinia kola seed. It is also conjectured that the documented antibacterial, anti-inflammatory, anti-spasmodic, antidiabetic and antifertility effects of Garcinia kola seed may have underlying involvement of alterations in body levels of trace metals and electrolytes.

Key Words: Garcina kola seeds; electrolytes; trace metals

\section{Introduction}

Garcinia kola Heckel (Guttiferae) is a large fruit tree that abounds in the rain forest belt of Southern Nigeria. The seed ("bitter kola") is used in (Nigerian herbal medicine to treat diarrhoea, hepatitis, asthma, dysmenorrhea or menstrual cramps (Dalziel, 1937). The alkaloid and biflavonoid extracts of $G$. kola seed exhibited the following effects: dose-dependent spasmolytic effects on uterine and gastrointestinal smooth muscle (Braide, 1989); deterioration of reproductive function (Braide et al, 2003); anti-inflammatory and antipyretic effects (Braide, 1993); antihepatotoxic effect (Akintonwa and Essien, 1990; Braide, 1991; Iwu et al, 1987); and antidiabetic activity (Iwu et al, 1990).

Chronic ingestion of $G$. kola seed was observed to induce histopathological changes in liver parenchymal cells, renal tubular epthelium and duodenal villous epithelium (Braide, 1990; Braide and Grill, 1990). The ingestion of G. kola seed also caused mild bronchodilation in man (Orie and Ekon, 1993). Other effects of $G$. kola seed extracts include protection against carbon tetrachloride induced erythrocyte damage (Adaramoye and Akinloye, 2000) and inhibitory effect on lipid peroxidation (Adegoke et al, 1998; Farombi et al, 2000; Farombi, 2002; Farombi et al, 2002; 2004). These spectra of effects, directly or indirectly, involve at the biochemical level electrolytes ant trace metals. For example, the spasmolytic effect of $G$. kola seed on smooth muscle could be due to inhibition of transmembrane influx of calcium ions into the cytosol.
Hisataka et al, (2004) studied the effects of various concentrations of electrolytes $\left(\mathrm{Na}^{+}\right.$, $\mathrm{K}^{+}, \mathrm{Ca}^{2+}, \mathrm{Mg}^{2+}$ ) on the developmental competence of bovine oocytes and demonstrated that magnesium concentration increased blastulation rate, follicle size and maturation, as well as development of the oocyte. It is noteworthy that electrolytes and trace metals gain entry into the body mainly from dietary sources via gastrointestinal ingestion (Linder 1991); and trace metals (eg. Zinc) are accumulated in organs such as kidney, liver, pancreas and gonads (Mc Cormick and Cunningham, 2005). Testicular atrophy has been associated with depletion of zinc in the testis; while increased zinc in the prostate and decreased zinc in the testis are correlated with age and decline in testicular activity (Oldereid et al, 2005).

Several lines of evidence indicate that the development of atherosclerosis is related to free-radical activity, lipid peroxidation and oxidative modifications of low-density lipoproteins (LDL). Natural antioxidants such as the enzyme copper, zinc superoxide dismutase (Cu, $\mathrm{Zn}$ SOD) abound. Since zinc is an essential component of $\mathrm{Cu}, \mathrm{Zn}$ SOD, any deficiency of zinc could induce an increase in tissue oxidative damage (Disilvestro and Bloteinfujii, 1997). Garcinia kola seed has been shown to exert antioxidant activity (Farombi et al, 2002; Farombi et al, 2004) and this observation may not be unconnected with alterations in the levels of zinc in serum, and hence the body. The objective of this study is to determine if oral doses of whole seed 
P. O. Agada and V. B. Braide

formulations of $G$. kola have any effect on serum concentrations of electrolytes $\left(\mathrm{Na}^{+}, \mathrm{K}^{+}\right.$, $\mathrm{CI}^{-}, \mathrm{HCO}_{3}^{-}, \mathrm{Mg}^{2+}, \mathrm{Ca}^{2+}$ ) and trace metals $\left(\mathrm{Zn}^{2+}, \mathrm{Cu}^{2+}, \mathrm{Mn}^{2+}\right)$ in experimental animals.

\section{Materials and methods \\ Animals}

The animals used in the study were young adult, virgin male albino rats $100-150 \mathrm{~g}$ body wt. obtained from the animal house of the Department of Pharmacology, University of Calabar, Nigeria. The rats were randomly selected into groups, consisting of five rats per group, housed in standard rat cages (one rat per cage) and maintained for two weeks prior to the study, to allow for acclimatization and uniform husbandry conditions of light $(14 \mathrm{~h}$ light and $10 \mathrm{~h}$ darkness) and ambient room temperature $\left(28-30^{\circ} \mathrm{C}\right)$. The animals were fed with a standard rat mash (Pfizer Feeds, Aba, Nigeria) and received food and tap water $a d$ libitum.

Preparation of Plant Material and Administration

Fresh seeds of Garcinia kola, purchased in season from the local markets in Calabar, Nigeria, were peeled to remove the testa, washed and air dried for $10 \mathrm{hrs}$, prior to drying in an oven at $40^{\circ} \mathrm{C}$ for 12 hours. The dried seeds were then ground to a fine powder with the aid of mortar and pestle.

Four batches of feed mixture were made available for use in the study: control feed sample containing no Garcinia kola seed powder; feed samples that contained Garcinia kola seed powder at levels of 5\% (w/w), 10\% $(\mathrm{w} / \mathrm{w})$ and $20 \%(\mathrm{w} / \mathrm{w})$ respectively. The control feed and the Garcinia kola feed mixtures were fed to the rats for 6 weeks; on pair-fed basis.

\section{Collection and Handling of Blood Serum}

The animals were anaesthetized in a chloroform chamber at the end of feeding period of 6 weeks, and blood was obtained through cardiac puncture. Blood samples from each animal were put in well-labeled nonheparinized sample tubes which were then allowed to stand for $3 \mathrm{~h}$ in iced water and later centrifuged at $7,000 \mathrm{~g}$ for 10 minutes. The serum was then collected and stored at $-15^{\circ} \mathrm{C}$ until ready for use.

\section{Analytical Methods}

Serum zinc, copper and manganese concentrations were determined as follows: Aliquots of serum were predigested with concentrated nitric acid (HNO3) followed by further digestion with a mixture (10:3) of concentrated $\mathrm{HNO}_{3}$ and concentrated perchloric acid $\left(\mathrm{HCIO}_{4}\right)$. The acid samples were heated in a $50 \mathrm{ml}$ pyrex beaker, covered with a watch glass of suitable size, on an electric hotplate. The heating was continued till all traces of $\mathrm{HCIO}_{4}$ were eliminated, as was indicated by a cessation of white fume production in the beaker. The final liquid volume in the digestion beaker (about $2 \mathrm{ml}$ ) was made up to $25 \mathrm{ml}$ with deionized water and assayed for $\mathrm{Zn}, \mathrm{Mn}$ and $\mathrm{Cu}$ with an atomic absorption spectrphotometer (Jarrell -Ash Model 82-362) (Braide, 1973). Serum levels of cation electrolytes were estimated by flame photometry while the serum levels of anion electrolytes were estimated by titration procedures for chloride and bicarbonate.

\section{Statistical Analysis}

All data for control and experimental animals were subjected to statistical evaluation, using the Student's t-test for significance of differences between control and experimental groups, at values of $\mathrm{P}<0.05$.

\section{Results}

Effect of G. kola seed diet on serum electrolytes

Male rats fed for 6 weeks on diets containing various levels of $G$. kola seed powder (G KP) were studied at the end of the feeding period. The diets contained GKP at levels of $5 \% \mathrm{w} / \mathrm{w}(9 \mathrm{~g} / \mathrm{kg} /$ day $), 10 \% \mathrm{w} / \mathrm{w}(18 \mathrm{~g}$ $/ \mathrm{kg} /$ day) and $20 \% \mathrm{w} / \mathrm{w}(36 \mathrm{~g} / \mathrm{kg} /$ day $)$. The GKP diet caused significant $(\mathrm{p}<.05)$ increase in serum concentrations of calcium and magnesium, when fed at levels of $10 \% \mathrm{w} / \mathrm{w}$ or higher. The effect of GKP diet was also marked at the level of $5 \% \mathrm{w} / \mathrm{w}$, in the case of serum magnesium concentrations (Table 1). There were no marked changes in the serum concentrations of sodium and potassium. (Table1). The effect of GKP diet was also marked on serum levels of chloride and bicarbonate in rats fed diets containing at least10-20\% w/w GKP (Table 2). 
Effect of dietary G. kola seed on selected serum electrolytes

Table 1. Effects of Garcinia kola seed powder (GKP) diet on cation electrolyte levels in serum of male rats after feeding for 6 weeks.

\begin{tabular}{|c|c|c|c|c|}
\hline \multirow[t]{2}{*}{ Diet $^{a}$} & \multicolumn{4}{|c|}{ Serum concentration ${ }^{b}$} \\
\hline & $K^{+}(m M / l)$ & $\mathrm{Na}^{+}(\mathrm{mM} / \mathrm{l})$ & $\mathrm{Ca}^{2+}(\mathrm{mg} / \mathrm{m})$ & $\mathrm{Mg}^{2+}(\mathrm{mg} / \mathrm{ml})$ \\
\hline Controls & 2.64 & 137 & 620 & 30.44 \\
\hline $0 \%$ GKP (5) & \pm 0.1 & \pm 2.45 & \pm 103.7 & \pm 12.1 \\
\hline $5 \%$ w/w GKP (5) & $2.74 \pm 0.22$ & $\overline{1} 36 \pm 2.07$ & $\overline{8} 41.5+151.4$ & $80.44 \pm 2.7 *$ \\
\hline $\begin{array}{l}10 \% \text { w/w GKP } \\
\text { (5) }\end{array}$ & $2.88+0.22$ & $138+1.79$ & $1,039 \pm 175^{*}$ & $160.32 * \pm 35.2$ \\
\hline $\begin{array}{l}20 \% \text { w/w GKP } \\
\text { (5) }\end{array}$ & $2.96+0.25$ & $138+0.71$ & $1,515^{*}+157.2$ & $502.5^{*}+303.8$ \\
\hline
\end{tabular}

* Significantly different from controls $(p<0.05)$. (a) Number in parenthesis represents the number of animals in each diet group. (b) The values represent means \pm S.D.

Table 2. Effects of Garcinia kola seed powder (GKP) diet on anion electrolyte levels in serum of male rats after feeding for 6 weeks.

\begin{tabular}{|c|c|c|}
\hline \multirow[t]{2}{*}{ Diet $^{a}$} & \multicolumn{2}{|c|}{ Serum concentration $(\mathrm{mM} / 1)^{b}$} \\
\hline & Chloride & Bicarbonate \\
\hline $\begin{array}{lll}\text { Control } & 0 \% & \text { GKP } \\
\text { (5) } & & \end{array}$ & $97.6 \pm 3.6$ & $23.4 \pm 0.5$ \\
\hline $5 \%$ w/w GKP (5) & $97.0 \pm 1.6$ & $24.8 \pm 0.8$ \\
\hline $10 \%$ w/w GKP (5) & $102.4 \pm 1.8^{*}$ & $24.4 \pm 0.5$ \\
\hline $20 \%$ w/w GKP (5) & $103.8 \pm 1.3^{*}$ & $27.0 \pm 0.7 *$ \\
\hline
\end{tabular}

* Significantly different from controls $(\mathrm{p}<0.05)$, (a) Number in parenthesis represents the number of animals in each diet group, (b) The values represent means \pm S.D

Table 3. Effects of Garcinia kola seed powder (GKP) diet on levels of copper, zinc and manganese in serum of male rats after feeding for 6 weeks.

\begin{tabular}{llll}
\hline Diet $\left(^{\mathrm{a}}\right)$ & \multicolumn{3}{l}{ Serum concentration $(\mathrm{mg} / \mathrm{ml})\left({ }^{\mathrm{b}}\right)$} \\
& $\mathrm{Cu}$ & $\mathrm{Zn}$ & $\mathrm{Mn}$ \\
\hline Controls & & & \\
$0 \%$ GKP (5) & $11.6 \pm 3.53$ & $2.44 \pm 0.49$ & $0.40 \pm 0.71$ \\
$5 \%$ w/w GKP (5) & $16.3 \pm 2.40$ & $3.54 \pm 0.68$ & $0.64 \pm 0.09$ \\
$10 \%$ w/w GKP (5) & $25.6 \pm 4.48$ & $3.96 \pm 0.44$ & $0.86 \pm 0.17$ \\
20\% w/w GKP (5) & $54.8 \pm 3.91^{(*)}$ & $6.80 \pm 2.18^{(*)}$ & $1.44 \pm 0.43^{(*)}$ \\
\hline
\end{tabular}

(*) Significantly different from controls $(\mathrm{p}<0.05)$, (a) Number in parenthesis represents the number of animals in each diet group. (b) The values represent means \pm S.D

\section{Discussion}

This study has shown that in male young adult rats, following ingestion of Garcinia kola seed for six weeks, there was marked doesdependent elevation in serum concentrations of chloride, bicarbonate, calcium, magnesium, copper, zinc and manganese. The observed changes in concentrations of the electrolytes (anionic and cationic) and the trace metals $(\mathrm{Cu}$, $\mathrm{Zn}, \mathrm{Mn}$ ) could have considerable implications for therapeutic and toxicological responses, following the use of G.kola seeds in traditional medicine.

Calculations of the anion gap from results presented in Tables 1 (for $\left[\mathrm{Na}^{+}\right]$and $\left[\mathrm{K}^{+}\right]$) and 2 (for $\left[\mathrm{Cl}^{-}\right]$and $\left[\mathrm{HCO}_{3}{ }^{-}\right]$) suggest clearly a dose- dependent decrease in the value for anion gap, as follows: Controls $(18.64 \mathrm{mmol} / \mathrm{L}) ; 5 \%$ w/w GKP $(16.94$ $\mathrm{mmol} / \mathrm{L}) ; 10 \% \mathrm{w} / \mathrm{w}$ GKP $(14.08 \mathrm{mmol} / \mathrm{L})$; and $20 \% \mathrm{w} / \mathrm{w}$ GKP $(10.16 \mathrm{mmol} / \mathrm{L})$. The decrease in anion gap, in response to increasing dosage of GKP treatment is due to the increased levels of chloride and bicarbonate in serum; especially when the GKP dosage was as high as $20 \%(\mathrm{w} / \mathrm{w})$ in the diet. The anion gap is usually increased in most cases of metabolic acidosis. In this study, GKP could not have been said to induce metabolic acidosis, since the anion gap was markedly decreased. It is suggested that GKP may 
have induced some kind of metabolic alkalosis; since the bicarbonate level in serum was markedly elevated. The anion gap represents those negative ions not normally measured routinely in clinical practice, including phosphate, sulphate, lactate, ketoacids and albumin. A subsequent study (Odubayo, 2009) showed no indication that G.kola seeds had any effect on serum albumin levels.

It is noteworthy that GKP also caused marked dose-dependent enhancement of the serum levels of calcium, magnesium, copper, zinc and manganese. Calcium is the main ion carrying the inward current during the rising phase of the action potential in smooth muscle; and spontaneous action potentials in guinea pig taenia coli and uterus are also dependent on the calcium concentration, whereas manganese blocks the production of action potentials in smooth muscles. Although excess calcium in extracellular fluid may increase the amplitude of action potential and enhance smooth muscle contractility, these effects are opposed by the membrane stabilization produced by calcium. Braide (1989) and Udia (1998) attributed the antispasmodic and spasmolytic effect of Garcinia kola seed extracts to possible reduction of calcium ion entry into the cytosol of smooth muscle cells and/or the sequestration of calcium ions in the extracellular fluid and/or active calcium extrusion from the cytosol thereby ridding the contractile apparatus in cytosol of $\mathrm{Ca}^{2+}$ essential for generation and sustenance of smooth muscle contraction. The enhanced serum levels of calcium and manganese, as observed in the present study, could conceivably explain the effect of Garcinia kola seed on smooth muscle activity.

The serum level of copper was markedly increased by treatment with Garcinia kola seed. Caeruloplasmin is the alpha-2-globulin that complexes with copper in blood; and without caeruloplasmin, there is a rise of free (unbound) copper in the blood along with excessive entry of $\mathrm{Cu}^{2+}$ into tissues (Lee et al., 1976). It is of interest to recall the study by Odubayo (2009) which showed that the extract from Garcinia kola seed did reduce markedly the globulin fraction of serum proteins in rats. The observed increases in manganese, copper and zinc levels in serum, following consumption of Garcinia kola seed, lends credence to the conclusion drawn from studies (Disilvestro and Blotein-Fujii, 1997) in which the natural antioxidants, copper-zinc superoxide dismutase and manganese superoxide dismutase, were implicated in protection against oxidative damage to tissues, free radical activity and lipid peroxidation of cell membranes.

\section{Acknowledgements}

The contents of this paper formed part of a thesis submitted by P.O.A. to the Graduate School, University of Calabar, in partial fulfillment of the requirements for the award of M.Sc. degree in Pharmacology.

\section{References}

Adaramoye, O.A. and Akinloye, O. (2000). Possible protective effect of kolaviron on $\mathrm{CCl}_{4}$-induced erythrocyte damage in rats. Biol. Sci. Reposit. 20(4): 259 - 264.

Adegoke, G. O.,Kumar, M. V., Sambiah, K and Lokeshi, B.R. (1998). Inhibitory effect of Garcinia kola on lipid peroxidation in rat liver homogenate. Indian J. Exp. Biol. 36:907-910

Akintonwa, A. and Essien, A. R. (1990).Protective effects of Garcinia kola seed extract against paracetamolindiced hepatotoxicity in rats. $J$. Ethnopharmacol. 29(2): 207-211

Braide, V. B. (1973). Aspects of CaEDTA toxicity in rats. Ph.D. Thesis, Cornell University, Ithaca, New York, U.S.A

Braide, V. B. (1989). Antispasmodic extracts from seeds of Garcinia kola. Fitoterapia LX : 123 - 129.

Braide, V. B. (1990). Pharmacological effects of chronic ingestion of Garcinia kola seeds in rats. Phytother. Res. 4: 39-41.

Braide, V. B. and Grill, V. (1990). Histological alterations by a diet containing seeds of Garcinia kola: effect on liver, kidney intestine in the rat. Gegenbaurs Morphol. Jahrb. 136(1): 95-101.

Braide, V. B. (1993). Anti-inflammatory effect of kolaviron, a biflavonoid extract of Garcinia kola seeds in rats. Fitoterapia LXIV (5): 433 -436.

Braide, V. B., Agube, C.A., Essien, G. E. and Udoh, F.V. (2003). Effect of Garcinia kola seed alkaloid extract on levels of gonadal hormones and pituitary gonadotrophins in rat serum. Niger. J. Physiol. Sci.ences 18: 59-64.

Dalziel, J. M. (1937). Flora of West Tropical Africa. (2 ${ }^{\text {nd }}$ edition) H.M.O. London vol.1, p. 295. Dalziel, J. M. (1956). Useful plants of Tropical Africa. London: Crown Agents, pp. 612-617.

Disilvestro, R. A. and Blotein-Fujii, A. (1997) Moderate zinc deficiency in 
rats enhances Lipoprotein oxidation in vitro. Free Rad. Biol. Med. 22:739-742.

Farombi, O. E., Tahnteng, J. G., Agbooola, A.O., Nwankwo, J.O. and Emerole, G. O. (2000). Chemoprevention of 2acetylaminofluorence-induced hepatotoxicity and lipid peroxidation in rats by kolaviron, a Garcinia kola seed extract. Food Chem. Toxicol. 38:535 541

Farombi, O. E. (2000). Mechanisms for the hepatoprotective action of kolaviron: studies on hepatic enzymes, microsomal lipids and lipid peroxidation in carbon tetrachloride treated rats. Pharmacol. Res. 42: 75-80.

Farombi, O.E., Akanni, O.O. and Emerole, G.O. (2002). Antioxidant and Scavenging activities of flavonoid extract (Kolaviron) of Garcinia kola seeds. J. Pharm. Biol. 40: 107-116.

Farombi, O.E., Moller, P. and Gragsted, L.O. (2004). Ex-vivo and in vitro protective effects of kolaviron against oxygen derived radical - induced DNA damage and oxidative stress in human lymphocytes and rat liver cells. Cell Biol. Toxicol. 20:71 - 82.

Hisataka, I., Shu, H., Mayuko, O., Koji, K., Kenichi, S. and Masashi, M. (2004). Effect of follicle size and electrolytes and glucose in maturation medium on nuclear maturation and development competence of bovine oocytes. Reproduction 127:159 -164 .

Iwu, M. M., Igboko, O. A., Okunji, C.O. and Tempesta, M. S. (1990). Antidiabetic and aldose reductase activities of biflavones of Garcinia kola. J. Pharm. Pharmacol. 42: $290-292$.
Lee, G. K., Williams, D. M. and Cartwright, G.E. (1976). Role of copper in iron metabolism and heme biosynthesis. In, Trace Elements in Human Health and Disease. Vol. 1. Zinc and Copper. (Prasad, A. S. and Oberleas, D., eds.) Academic Press Inc., New York, 1976, pp. 373 - 390.

Linder, M. C. (1991). Nutritional Biochemistry and Metabolism with clinical Applications, $2^{\text {nd }}$ ed., Appleton and Lange, Norwalk, CT, USA.

Mc Cormick, C. C. and Cunningham, D. I. (2005). Forced resting by high dietary zinc: tissue zinc accumulation and reproductive organ weight changes. Entrez Pub. Med. File: A: trace 2.htm

Odubayo, M. A. (2009). Selected aspects of disposition profile of Kolaviron and effect of kolaviron on blood proteins in female albino rats. M.Sc. Thesis, University of Calabar, Calabar, Nigeria.

Oldereid, N. B., Thomassn, Y., Attramadal, A., Oleisen, B. and Puvis, K. (2005) Concentration of Lead, Cadmium and Zinc in the tissue of reproductive organs of men. Entrez Pub. Med. File: A: trace 1.htm.

Orie, N. N. and Ekon, E. U. (1993). The bronchodilator effect of Garcinia kola. East Afr. Med. J. 70: 143 - 145.

Udia, P. M. (1998). Effect of Garcinia kola extracts on selected smooth muscle preparations of guinea pigs and albino rats. M.Sc. Thesis, University of Calabar, Calabar. Nigeria. 